\title{
The sky is the limit?: The determinants and constraints of European airports' commercial revenues
}

Article

Accepted Version

Fuerst, F., Sven, G. and Ulf, K. (2011) The sky is the limit?: The determinants and constraints of European airports' commercial revenues. Journal of Air Transport Management, 17 (5). pp. 278-283. ISSN 0969-6997 doi:

https://doi.org/10.1016/j.jairtraman.2011.03.001 Available at https://centaur.reading.ac.uk/22848/

It is advisable to refer to the publisher's version if you intend to cite from the work. See Guidance on citing.

Published version at: http://www.sciencedirect.com/science/article/pii/S0969699711000445

To link to this article DOI: http://dx.doi.org/10.1016/j.jairtraman.2011.03.001

Publisher: Elsevier

All outputs in CentAUR are protected by Intellectual Property Rights law, including copyright law. Copyright and IPR is retained by the creators or other copyright holders. Terms and conditions for use of this material are defined in the End User Agreement.

www.reading.ac.uk/centaur 
Central Archive at the University of Reading

Reading's research outputs online 


\section{Real Estate \& Planning}

\section{Working Papers in Real Estate \& Planning 14/10}

The copyright of each Working Paper remains with the author.

If you wish to quote from or cite any Paper please contact the appropriate author. In some cases a more recent version of the paper may have been published elsewhere. 


\title{
The Sky is the Limit? The Determinants and Constraints of European Airports' Commercial Revenues
}

FRANZ FUERST*

HENLEY BUSINESS SCHOOL

UNIVERSITY OF READING
SVEN GROSS

HARZ UNIVERSITY OF APPLIED SCIENCES
ULF KLOSE

AIRPORT REAL ESTATE

\begin{abstract}
This study investigates the determinants of commercial and retail airport revenues as well as revenues from real estate operations. Cross-sectional OLS, 2SLS and robust regression models of European airports identify a number of significant drivers of airport revenues. Aviation revenues per passenger are mainly determined by the national income per capita in which the airport is located, the percentage of leisure travelers and the size of the airport proxied by total aviation revenues. Main drivers of commercial revenues per passenger include the total number of passengers passing through the airport, the ratio of commercial to total revenues, the national income, the share of domestic and leisure travelers and the total number of flights. These results are in line with previous findings of a negative influence of business travelers on commercial revenues per passenger. We also find that a high amount of retail space per passenger is generally associated with lower commercial revenues per square meter confirming decreasing marginal revenue effects. Real estate revenues per passenger are positively associated with national income per capita at airport location, share of intra-EU passengers and percent delayed flights. Overall, aviation and non-aviation revenues appear to be strongly interlinked, underlining the potential for a comprehensive airport management strategy above and beyond mere cost minimization of the aviation sector.
\end{abstract}

Keywords: Commercial revenues, non-aviation activities, European airports, regression analysis

* Corresponding author, contact details: School of Real Estate \& Planning, Whiteknights, Reading, RG6 5TL United Kingdom, f.fuerst@ henley.reading.ac.uk, phone: +44 1183786035 


\section{INTRODUCTION}

Modern airports have evolved far beyond the functional infrastructure facilities they were in the past: Shops, restaurants, convention centers and even entertainment facilities such as museums and expositions are all part of a strategy to expand the non-transport services airports are offering. In line with these developments, revenues from non-aviation and commercial activities have grown considerably in the past two decades and match or even exceed the aviation revenues of some airports. The reasons for the intensified commercialization and experience staging are manifold; the most frequently named are changing consumer behavior and cost pressure in airline business along with low profit margins in airport management due to the ongoing deregulation process in Europe. As these underlying drivers are likely to persist or strengthen for years to come, non-aviation profit centers are set to become even more pivotal for airport profits.

The share of non-aviation revenues in total revenues varies considerably across airports and regions. In North America and Africa/Middle East, non-aviation revenues have typically a share of more than half of total revenues, while they account for only $46-48 \%$ of revenues in Europe and Asia/Pacific and about $30 \%$ in the Caribbean and Latin America region. Within Europe, this share ranges from $20 \%$ to more than $60 \%$ for some airports. The most important income sources for global non-aviation revenues are retail (22\%), property (19\%) and car parking (18\%) (Graham 2009; ACI 2005 - 2008).

To run their non-aviation business efficiently, airports need to determine underlying business parameters, for instance the optimal size and configuration of commercial space in the airport as well as the optimal combination of facilities and non-aviation offers. This study sets out to analyze the determinants of and interactions between these parameters. The findings derived from our analysis can be used to predict and optimize commercial revenues in the non-aviation sector of airport operations.

The remainder of this article is organized as follows. After a review of the extant literature, we describe the data collection process and the analytical approach. An exploratory data analysis in the next section will be followed by a discussion of the results obtained from various regression models. Finally, the ramifications of the empirical findings for airport planning and retail management along with the prospects for future research are explored.

\section{STATE OF RESEARCH}

The importance of non-aviation activities in general and the retail segment in particular has been emphasized by practitioners and researchers alike (The Moodie Report 2009, Freathy 2004, Graham 
2009, Benham 2009), but rigorous empirical analyses of the topic are still scarce. Research on the nonaviation business is often focused on a particular aspect such as parking space management or airport city concepts (e.g. Aldridge et al. 2001; Appold and Kasarda 2009; Poungias 2009) rather than a comprehensive analysis of commercial revenues and their determinants.

A relatively well-researched area of commercial revenues is airport retail. Various studies explore pertinent issues such as contractual and legal arrangements (Freathy and O'Connell 1999; Kim and Shin 2001), marketing and consumer studies (Geuens et al. 2004) and the microspatial allocation strategies within airport terminals (Hsu and Chao 2005). Very few of these studies apply econometric techniques, however. Torres et al. (2005) use a non-parametric approach to study the impact of waiting time on commercial revenues while Appold and Kasarda (2006) use regression analysis to identify drivers of airport sales both in total and per passenger. Using a panel data framework, Volkova (2009) investigates the drivers of retail revenues and identifies a distinct set of drivers for hub and regional airports. More recently, Castillo-Manzano (2010) has analyzed large-scale consumer surveys with econometric methods to determine the factors influencing food and beverage consumption and propensity to make a purchase.

An overview of studies on commercial revenues at airports and their main findings is provided in Table 1. While the extant studies have contributed significantly towards reaching a better understanding of commercial activities of airports, they are typically limited to a single country such as the USA or Spain, to name the two countries where most of the previous research was conducted. This study sets out to overcome the limited generalizability of single-country studies by analyzing a cross-section of airports in 19 countries. Additionally, this study is among very few that analyze revealed preferences from revenue data rather than the stated preference studies based on consumer surveys.

Despite the large variation in study areas and methods across previous studies, a number of factors emerge as key drivers of commercial revenues. These are primarily the size of the airport and the number of passengers required to support a range of specialized retail outlets, the supply of retail space, average flight time and the share of international flights. With regard to the latter, Castillo-Manzano (2010) notes that it may be more effective growing retail revenue if the number of trips is increased with the same number of passengers rather than looking to increase passenger numbers alone. Martel's (2009) main finding is that aviation and non-aviation revenues are closely interlinked which is confirmed by the empirical results presented in this paper. Zhang and Zhang (1997) demonstrated in a theoretical paper that some form of cross-subsidization between non-aviation and aviation activities may be desirable. In a similar vein, Morrison (2009) points out that the governance structure of an airport is crucial for the impact non-aviation revenues have on aviation prices and infrastructure. Where single-till price caps 
affect non-complementary non-aviation revenues competition could be tilted unfairly in that aviation prices will be lower, putting airports without single-till regulation at a considerable disadvantage.

The studies of demand composition detailed in Table 1 generally indicate that leisure travelers tend to spend more money than business travelers. It is likely that this is mainly a function of their longer average airport dwell time and a greater propensity to make retail and food purchases when on a leisure trip. A number of demographic and social factors are also reported to be influential:

- Families with children are more likely to make a purchase or to consume food/beverages, but this factor is also the greatest curb on the amount spent,

- Elderly people are less likely to make a purchase or to consume food/beverages,

- People in a group consume more food/beverages than passengers traveling on their own,

- Passengers that are seen off by a friend or relative are more likely to make a food and beverage purchase together with the accompanying individual.

The drivers identified in these earlier studies will now be tested in the empirical analysis of this study (with the exception of detailed demographic and socio-economic passenger profiles which were not available for a large number of airports). 
Table 1: Overview of selected studies on commercial airport revenues (+ positive influence, - negative influence)

\begin{tabular}{|c|c|c|c|}
\hline Authors & Study area and data & Method & Main determinants of commercial revenues \\
\hline $\begin{array}{l}\text { Torres et al. } \\
(2005)\end{array}$ & $\begin{array}{l}997 \text { passengers } \\
1 \text { airport in Spain }\end{array}$ & $\begin{array}{l}\text { non-parametric } \\
\text { approach }\end{array}$ & $\begin{array}{l}\text { - vacationers spend more money than business travelers }(+) \\
\text { - length of stay in airport prior to boarding }(+) \\
\text { - level of consumption is independent of the waiting time }\end{array}$ \\
\hline $\begin{array}{l}\text { Appold and } \\
\text { Kasarda (2006) }\end{array}$ & $\begin{array}{l}0 \text { passengers } \\
75 \text { airports in the US }\end{array}$ & OLS regression & $\begin{array}{l}\text { - number of passengers have the single largest effect on retail sales }(+) \\
\text { - average distance flown has an effect on food and beverage sales }(+) \\
\text { - type of airport: international gateway status, major tourist destination and clearance times }(-) \\
\text { - amount of retail space significant for sales per passenger }(+) \\
\text { - passenger traffic not significant for sales per passenger }(+)\end{array}$ \\
\hline$(2009)^{- \text {Cejas }}$ & $\begin{array}{l}0 \text { passengers } \\
26 \text { airports in Spain }\end{array}$ & $\begin{array}{l}\text { parametric } \\
\text { input distance } \\
\text { functions }\end{array}$ & $\begin{array}{l}\text { - proportion of international passengers circulating through the airport terminal }(+) \\
\text { - airports with well-developed commercial activities are more efficient than those that focus on aeronautical revenues }\end{array}$ \\
\hline Graham (2009) & $\begin{array}{l}\text { general information } \\
\text { about large number of } \\
\text { airports worldwide }\end{array}$ & $\begin{array}{l}\text { comparative } \\
\text { assessment of } \\
\text { data }\end{array}$ & $\begin{array}{l}\text { - leisure charter passengers are good shoppers }(+) \\
\text { - young leisure passengers who travel several times a year are high spenders }(+) \\
\text { - LCC passengers are good users of food beverage }(+) \\
\text { - foreigners with high duty and tax levels at origin buy more tax-free products }(+) \\
\text { - transfer passengers are less likely to make use of facilities and if they do, tend to spend less }(-)\end{array}$ \\
\hline $\begin{array}{l}\text { The Moodie } \\
\text { Report (2009) }\end{array}$ & $\begin{array}{l}0 \text { passengers, } \\
45 \text { airports worldwide }\end{array}$ & $\begin{array}{l}\text { among others } \\
\text { correlation } \\
\text { analysis }\end{array}$ & $\begin{array}{l}\text { - international and leisure passengers spend more because of longer dwell times and availability of duty free }(+) \\
\text { - large airports have more diverse, higher yielding commercial activities and ability to attract strong brands }(+) \\
\text { - share of domestic passengers inconclusive (neutral) } \\
\text { - increasing floor space indirectly generates better returns but not higher sales per passenger }(+/-)\end{array}$ \\
\hline $\begin{array}{l}\text { Volkova } \\
\text { (2009) }\end{array}$ & $\begin{array}{l}13 \text { airports } 13 \text { airports } \\
\text { from EU countries }\end{array}$ & $\begin{array}{l}\text { panel data } \\
\text { econometric } \\
\text { analysis }\end{array}$ & $\begin{array}{l}\text { - extra-EU passengers increase retail revenue per square meter at hub airports }(+) \\
\text { - number of short stay parking places, check-in facilities and the number of employees contribute to retail revenue }(+) \\
\text { - retail revenue per square meter grows significantly once critical mass of space is reached }(+) \\
\text { - bars/restaurants influence the retail revenue and generate externalities }(+) \\
\text { - extra-EU passengers have no effect on retail revenue at regional airports (neutral) }\end{array}$ \\
\hline $\begin{array}{l}\text { Castillo- } \\
\text { Manzano } \\
(2010)\end{array}$ & $\begin{array}{l}\text { over } 20000 \\
\text { passengers and } \\
7 \text { airports in Spain }\end{array}$ & $\begin{array}{l}\text { bivariate probit } \\
\text { model }\end{array}$ & $\begin{array}{l}\text { - waiting time prior to embarking, being on vacation, being a frequent flyer and traveling with children }(+) \\
\text { - number of group members and accompanied passengers explain the consumption of food/beverages }(+) \\
\text { - passengers from outside Eurozone more likely to consume food/beverages, albeit just loose change }(+) \\
\text { - passengers flying to international European destinations }(+) \\
\text { - elderly people purchase less and spend less on food/beverages }(-) \\
\text { - passenger's arrival at the airport on a courtesy bus by the hotel }(-) \\
\text { - business passengers not likely to make last-minute purchases at the airport (-) } \\
\text { - passenger using a LCC have a lower likelihood to purchase or consume food/beverages }(-)\end{array}$ \\
\hline
\end{tabular}




\section{DATA}

A major hurdle of any study of commercial revenues in Europe is that the relevant determinants are potentially as numerous as the airports for which information is available, thereby thwarting the application of econometric analytical techniques. To overcome this obstacle, our dataset is drawn from a large number of sources described below to maximize both the number of airports and the number of relevant variables.

The initial database comprised 54 major European airports with detailed information on a large set of indicators and key data on airport retailing (e.g. size of non-aeronautical space, branch revenues), aviation data (e.g. number of passengers, passenger structure) and macroeconomic indicators. Quantitative data on non-aviation activities are relatively scarce and definitions of key financial variables are less consistent than their aviation counterparts. There is no commonly recognized definition of what constitutes nonaviation activities (Zenglein and Müller 2007). This necessitated thorough checks of the definitions and methods as reported by the data providers to ensure consistency across all airports considered in this analysis. Applying this filter, data on eleven airports were found to be incompatible with common definitions and were subsequently excluded from the analysis (among others, all three Moscow airports and Milan Malpensa).

A further complication of the analysis is that a number of airport operators only publish aggregate revenue figures for all the airports under their management such as the British BAA Group, the Spanish AENA Group, the Portuguese ANA Group and Aéroports de Paris. In these cases, revenues for individual airports were obtained using information on the total number of passengers, the fee and cost structures of individual airports and other detailed information contained in the annual reports. In the next step, all monetary values were converted to Euros using the interbank exchange rate at the call date of the respective annual statements.

As there is no equivalent to the North American Airport Revenue News Factbook for European airports which would provide standardized non-aviation data for a large cross-section of airports, this part of our database had to be assembled using figures from various sources including the Association of European Airports (AEA), International Civil Aviation Organization (ICAO), Official Airline Guide (OAG), Airports Council International (ACI ) and Centre for Asia Pacific Aviation (CAPA). One of the core sources of our database is the Airport Commercial Revenue Study 2006/2007 \& 2008/2009 (The Moodie Report, $2007 \& 2009)$. In an effort to maximize the consistency of the multi-source database, additional telephone and email surveys with European airport operators were conducted. Having performed these 
steps, a database of 41 large European airports with more than 30 relevant indicators is available to identify the determinants of aviation and non-aviation revenues. Table A1 in the appendix contains a detailed overview of variable definitions.

\section{EXPLORATORY DATA ANALYSIS}

European airports cover a broad range of sizes, passenger structures and other characteristics that are potentially relevant determinants of aviation and non-aviation revenues. Given the large number of potential drivers relative to the number of airports, a preliminary step in the analysis is necessary to examine the distributions and summary statistics of the relevant variables in this heterogeneous sample before proceeding to formal regression modeling.

Table 2 examines several key characteristics of the dataset used in this analysis. As expected, standard deviations are relatively high for most variables, reflecting the broad range of values across the European airports considered in this study. A comparison of the values for different types of operations reveals that aviation operations are still the largest contributor to total revenues of European airports. Despite the aforementioned remarkable growth of non-aviation and commercial revenues worldwide, aviation revenues are on average more than fifty per cent higher than non-aviation revenues and more than three times higher than commercial revenues (based on median values) both as absolute amounts and on a per passenger basis. Revenues from real estate operations typically make up about one tenth of total revenues of an airport. Another noteworthy fact is the overall preponderance of leisure travelers and international travelers. The latter figure is of particular importance when comparing the results of this study to similar studies undertaken for North American airports where the share of domestic flights is typically much higher even for international hub airports. The median number of destinations in this dataset is 116 , which is reflective of the fact that our database mostly comprises large European airports. A caveat is therefore that the results of this analysis may not apply to smaller regional airports. 
Table 2: Summary Statistics

\begin{tabular}{|c|c|c|c|c|c|c|c|c|}
\hline & $\begin{array}{c}\text { Traffic } \\
\text { movements }\end{array}$ & $\begin{array}{l}\text { Retail space } \\
\text { (sq.m.) }\end{array}$ & $\begin{array}{c}\text { Aviation } \\
\text { revenue (mil. } \\
€)\end{array}$ & $\begin{array}{l}\text { Aviation } \\
\text { revenue per } \\
\operatorname{PAX}(€)\end{array}$ & $\begin{array}{l}\text { Non- Aviat. } \\
\text { revenue (mil. } \\
€)\end{array}$ & $\begin{array}{l}\text { Non-Aviat. } \\
\text { revenue per } \\
\operatorname{PAX}(€)\end{array}$ & $\begin{array}{l}\text { Commercial } \\
\text { revenue (mil. } \\
€)\end{array}$ & $\begin{array}{c}\text { Commercial } \\
\text { revenue per } \\
\operatorname{PAX}(€)\end{array}$ \\
\hline Mean & 194,076 & 15,492 & 272.10 & 12.02 & 153.45 & 6.96 & 71.02 & 3.71 \\
\hline Median & 166,688 & 10,927 & 161.50 & 10.77 & 93.23 & 6.69 & 51.95 & 2.75 \\
\hline Std. Dev. & 125,106 & 12,417 & 283.80 & 4.85 & 145.00 & 3.52 & 63.62 & 3.57 \\
\hline \multirow{2}{*}{ Observations } & 45 & 33 & 42 & 42 & 42 & 42 & 42 & 42 \\
\hline & $\begin{array}{l}\text { Real Estate } \\
\text { Rev. (mil. } € \text { ) }\end{array}$ & $\begin{array}{c}\text { Real Estate } \\
\text { Rev. PAX }(€)\end{array}$ & $\begin{array}{l}\text { Business } \\
\text { travel (\%) }\end{array}$ & $\begin{array}{c}\text { International } \\
\text { travel (\%) }\end{array}$ & $\begin{array}{l}\text { Origin of trip } \\
\quad(\%)\end{array}$ & $\begin{array}{l}\text { Punctual } \\
\text { arrivals (\%) }\end{array}$ & $\begin{array}{l}\text { Punctual } \\
\text { departs (\%) }\end{array}$ & $\begin{array}{l}\text { Number of } \\
\text { destinations }\end{array}$ \\
\hline Mean & 48 & 1.65 & $33.9 \%$ & $76.4 \%$ & $83.0 \%$ & $69.2 \%$ & $69.3 \%$ & 131 \\
\hline Median & 14 & 1.27 & $37.0 \%$ & $80.1 \%$ & $82.0 \%$ & $73.2 \%$ & $73.2 \%$ & 116 \\
\hline Std. Dev. & 67 & 1.41 & $12.4 \%$ & $17.9 \%$ & $15.0 \%$ & $14.1 \%$ & $14.0 \%$ & 55 \\
\hline Observations & 31 & 31 & 33 & 45 & 22 & 38 & 38 & 45 \\
\hline
\end{tabular}


Notwithstanding the exclusion of small airports, there are considerable variations regarding size and activity even within this sample. As Figure 1 shows, the top five airports (London Heathrow, Paris CDG, Frankfurt, Madrid and Amsterdam) capture a large share of passengers, followed by a secondary group comprised of London Gatwick, Munich, Rome and Barcelona and a larger group of airports with less than 20 million passengers a year making up more than half of the dataset. Despite the dynamic development of the aviation sector, the ranking of airports regarding passenger numbers has remained remarkably stable over the three-year period analyzed here.

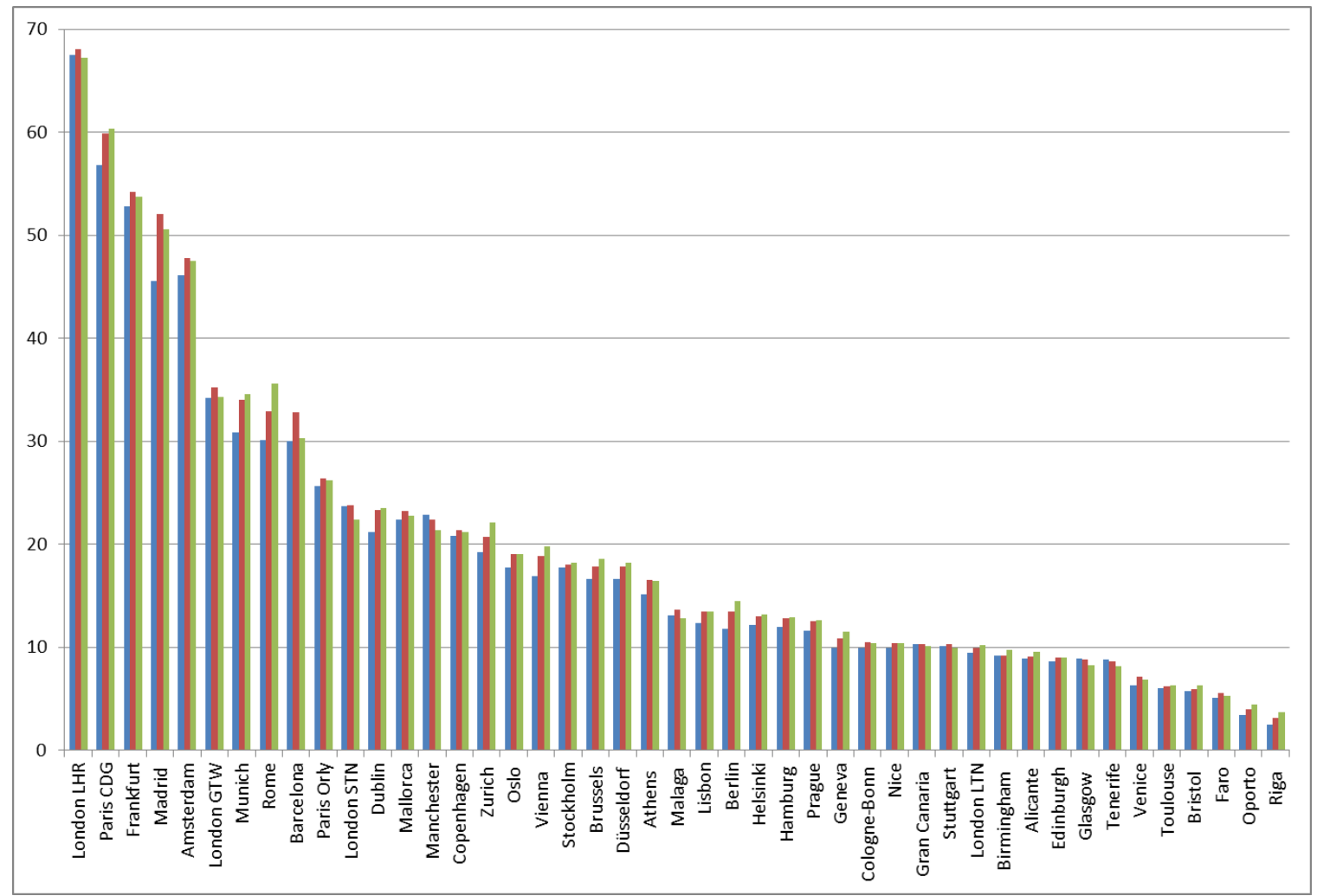

Figure 1: Total annual number of passengers in millions (1st bar=2006, 2nd bar=2007, 3rd bar=2008)

A notably different ranking emerges with respect to total revenues and revenue composition. Figure 2 shows that Frankfurt International Airport has the highest combined total revenue volume followed by Paris CDG, London Heathrow, Amsterdam and Munich. There are a number of airports with lower total revenue than would be expected from the ranking by number of passengers. London Gatwick and especially London Stansted are just two examples of airports exhibiting lower than expected total revenues. The breakdown by revenue types confirms the impression of the summary statistics that while 
non-aviation operations constitute an important component of total revenues they are not the predominant source of revenue for most airports. Despite individual differences, there appears to be a relatively strong connection between the magnitude of aviation and non-aviation revenues, which will be explored more formally in the regression analysis.

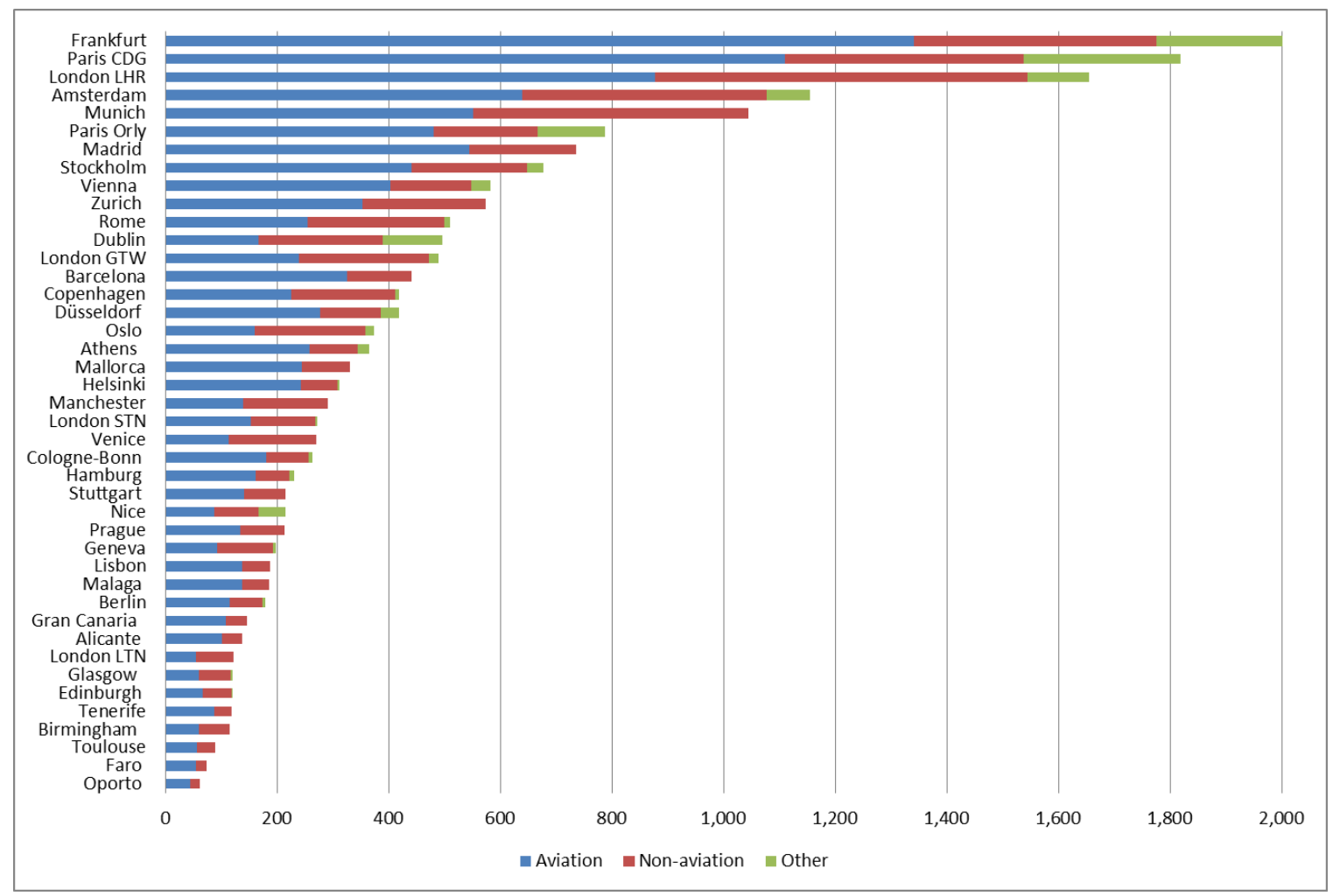

Figure 2: Revenue in million Euros from aviation, non-aviation and other operations by airport in 2008

Not surprisingly, size is an important determinant of airport revenues. By the same token, it may swamp the impact of less powerful factors. Figure 3 shows commercial revenue per passenger to eliminate the size effect of airports. The resulting ranking is remarkably different from the preceding figures. Four German airports (Munich, Cologne-Bonn, Dusseldorf and Hamburg) appear in the top ten while some of the largest airports, in particular Zurich, Paris and Brussels exhibit relatively low commercial revenues per passenger in 2008. A case in point are the four major London airports which have per passenger commercial revenues that are nearly in reverse order compared to airport size with Luton occupying a position near the top, Stansted in $12^{\text {th }}$ position while Heathrow and Gatwick exhibit values of approximately 3 Euros per passenger. This pattern appears to suggest that the share of low-cost carriers of an airport might impact commercial revenues per passenger positively. Earlier studies (for example Gillen and Lall, 2004, Papatheodorou and Lei, 2006) have found mixed or positive evidence regarding the 
consumption behavior of LCC passengers in airports but more recent evidence (Castillo-Manzano 2010) appears to suggest that LCC and full-service airline passengers are relatively similar in terms of behavior and needs for a variety of reasons. The picture emerging from our explanatory data analysis is that while some of the airports with the highest commercial revenue per passenger are also known to have a high share of LCC, the relationship is not clear cut and requires more formal investigation to substantiate.

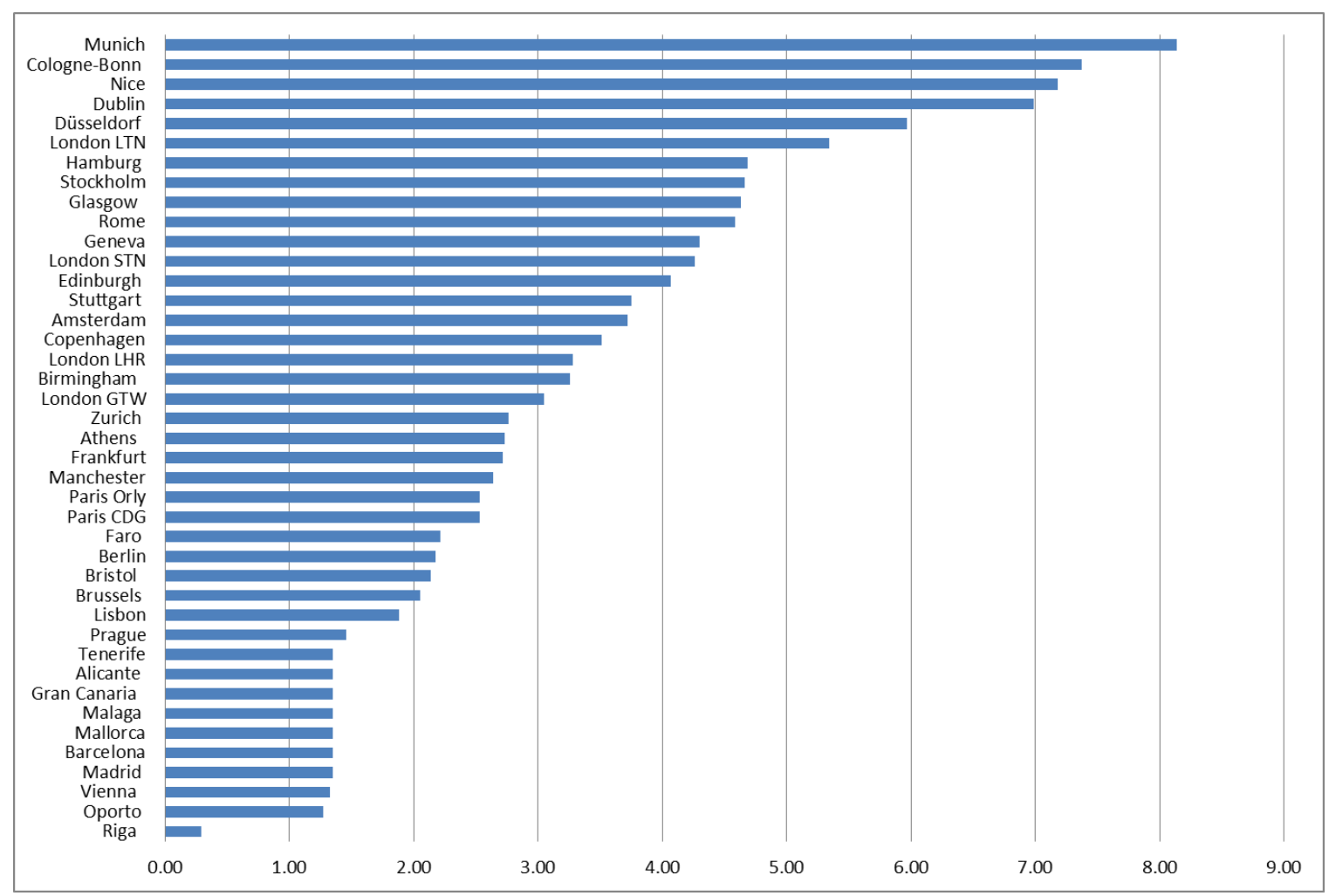

Figure 3: Commercial revenue in Euros per passenger in 2008

To visualize and contrast the role of airport size in aviation and commercial revenue more directly, Figure 4 shows scatter plots of aviation revenues and commercial revenues per passenger against total number of passengers. The nearest neighbor fitted lines suggest that aviation revenue per passenger tends to increase with airport size while the opposite appears to be the case for commercial revenue per passenger. As can be seen from the graphs, however, the relationship is not straightforward which warrants a more careful analysis in the following section.

The preliminary analysis of the data presented in this section suggests a number of important differences between aviation and commercial revenues. The next section will explore the differential impact of size 
and other structural characteristics in greater detail while controlling for confounding factors and potential endogeneity of some of these variables.
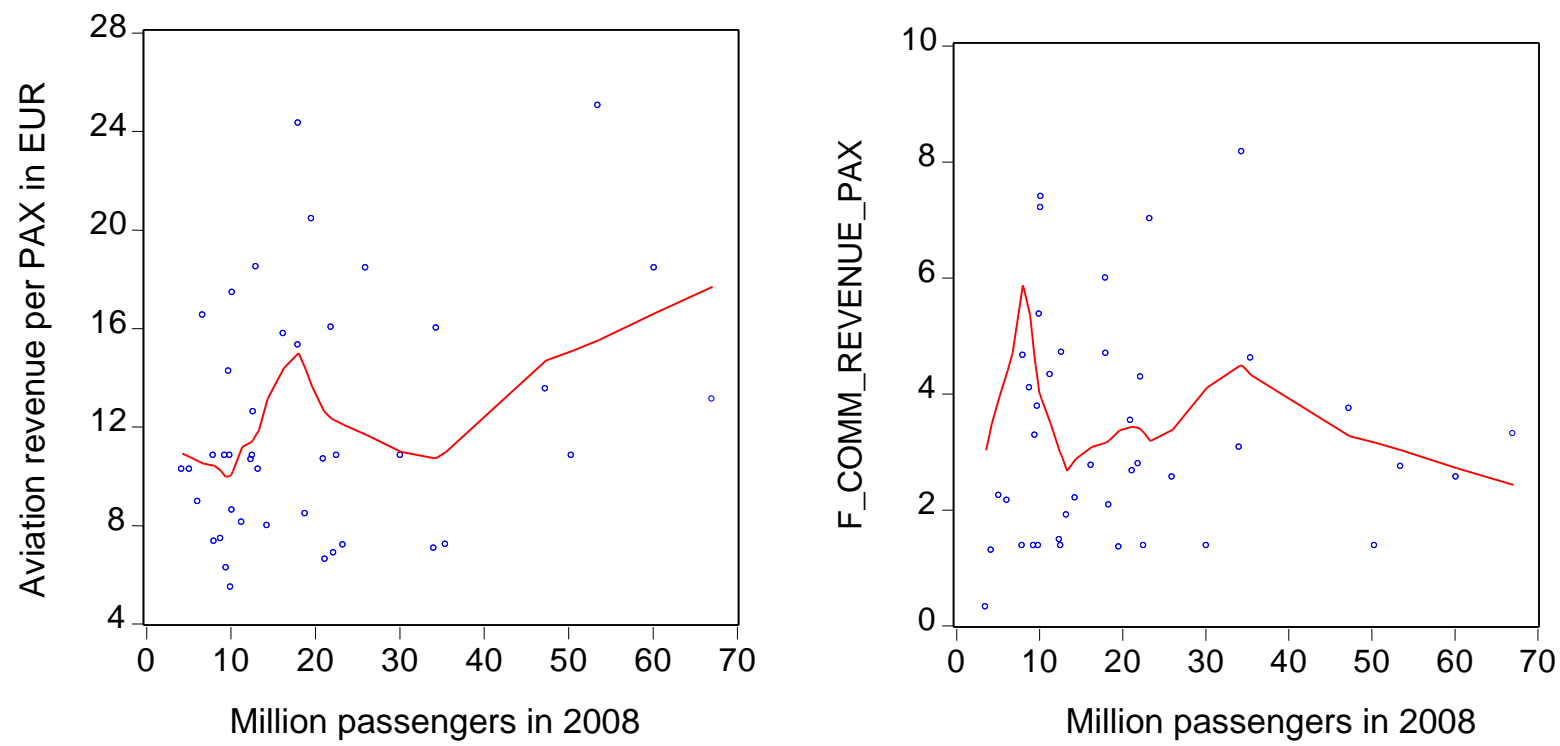

Figure 4: Scatter plots of aviation revenues and commercial revenues per passenger against total passengers with nearest neighbor fitted lines

\section{REGRESSION ANALYSIS}

Applying the data sample of 45 European airports described in the previous section, the determinants of non-aviation revenues are explored in a multivariate regression. In contrast to some of the previous studies on this topic, the limitations imposed by the moderate number of observations necessitated parsimonious model specifications with only the most significant determinants included in the regression model. Following the hierarchical order of revenue streams that airports accrue, aviation revenues are modeled first, followed by regression models of commercial revenues both absolute levels and at a per passenger level and finally revenues from real estate revenues.

\section{Aviation revenues}

The balance sheet positions pertaining to aviation-related revenues are still regarded as the core business of airports despite the recent growth in non-aviation revenues. These activities include all infrastructure related charges such as aircraft takeoff, landing and parking charges as well as passenger service fees. To provide a benchmark and enable a comparison with the determinants of non-aviation and commercial 
revenues, our first set of models predicts aviation revenues per passengers. Table 3 reports the coefficients resulting from the estimation. As expected, GDP/capita of the country in which the airport is located is positively associated with aviation revenues per passenger as is the percentage of leisure travelers although the latter is only significant at the 10 percent level. Interestingly, larger airports appear to also have higher aviation revenues per passenger and airports with a stronger emphasis on aviation activities in their balance sheets also generate higher revenues per passengers as opposed to airports with a focus on non-aviation revenues. This finding hints at a potential trade-off process between aviation and non-aviation revenues, at least when measured on a per passenger basis. Since two different measures of aviation revenues are included on both the left and the right hand side of Model 1 (absolute level and per passenger), Model 2 is a two-stage least squares estimation which instruments the level of aviation revenues. Although the diagnostic tests reveal that 2SLS is the more consistent and therefore more appropriate estimator, both coefficient sets are relatively similar.

Table 3: Regression models for aviation revenues per passenger ${ }^{1}$

\begin{tabular}{|c|c|c|c|c|}
\hline & $\begin{array}{c}\text { Model } 1 \\
\text { (OLS, log-log)) }\end{array}$ & & $\begin{array}{c}\text { Model 2 } \\
\left.(2 \mathrm{SLS}, \log -\log )^{2}\right)\end{array}$ & \\
\hline & Coefficients & & Coefficients & \\
\hline Constant & -7.14 & $* * *$ & -7.30 & $* * *$ \\
\hline GDP/capita & 0.50 & $* *$ & 0.59 & $* * *$ \\
\hline$\%$ leisure travelers & 0.08 & $*$ & 0.08 & $*$ \\
\hline Total aviation revenue & 0.27 & $* *$ & 0.23 & $* * *$ \\
\hline$\%$ aviation revenue of total & 1.53 & $* * *$ & 1.60 & $* * *$ \\
\hline Adj. R-squared & 0.79 & & 0.82 & \\
\hline F Test & 30.4 & & Chi sq.: 122.84 & \\
\hline F Prob & 0.00 & & 0.00 & \\
\hline No of obs & 31 & & 31 & \\
\hline
\end{tabular}

\footnotetext{
${ }^{1}$ White heteroskedasticity-consistent standard errors \& covariance in all model estimations

${ }^{2}$ Instrumented: $\log \_$aero_revenue, Instruments: $\log \_g d p c a p \_p p p \log$ pax_leisure_perc log_ratio_rev_aero_tot, $\log$ traffic_movem, Durbin (score) $\operatorname{chi} 2(1)=6.58(\mathrm{p}=0.01)$, Wu-Hausman $=6.74(\mathrm{p}=0.02)$, Hausman $5 . \overline{52}(\mathrm{p}=0.02)$
} 


\section{Commercial revenues}

The next set of models seeks to identify the major drivers of overall commercial revenue of an airport. The results of the regression analysis are reported in Table 4. As expected, the total number of passengers is found to be highly predictive of overall commercial revenue of an airport confirming that larger airports have a higher volume of commercial revenues. We also find that the ratio of commercial revenue to total revenue of an airport is a significant driver of the total commercial revenue volume, in line with the assumption that a stronger emphasis on non-aviation activities generates higher revenues. The level of economic development and wealth of the country in which the airport is located (proxied by GDP per capita) is again a significant driver of commercial revenue as higher spending power of the average passenger leads to higher commercial revenues ceteris paribus. Applying these three relatively simple measures in Model 1, we were able to predict $90 \%$ of the variation in commercial airport revenues. A possible problem with the specification of Model 1 is that some of its regressors might be endogenous. It appears plausible that commercial revenue, number of passengers and the ratio of commercial to total revenue are all jointly determined. Therefore, we estimate Model 2 as a 2SLS regression where the three questionable variables are used as instruments and only GDP/capita enters the second-stage regression in its original form. The predictive power of this model is somewhat lower as can be seen from the output shown in Table 4 but avoids potential specification problems. ${ }^{3}$

Model 3 applies variables mainly related to the passenger structure of an airport. Because these variables were only available for a subset of airports in the sample, we estimate a separate model. Somewhat surprisingly, we find that the share of domestic passengers is positively related to commercial revenue while the share of business travelers appears to be negatively related but does not meet the required significance level. The volume of traffic movements of an airport is positive and significant, as expected.

\footnotetext{
${ }^{3} \mathrm{~J}$ statistic for Model 2 on overidentifying restrictions of Model 2 is 0.18 (prob. 0.66) and endogeneity test difference in J-stats is 8.2 (prob. 0.00)
} 
Table 4: Regression models for Total Commercial Revenue

\begin{tabular}{|c|c|c|c|c|c|c|}
\hline & $\begin{array}{c}\text { Model } 1 \\
\text { (OLS, log-log) } \\
\end{array}$ & & $\begin{array}{c}\text { Model } 2 \\
\text { (2SLS, log-log) }\end{array}$ & & $\begin{array}{c}\text { Model 3 } \\
\text { (OLS, log-log) } \\
\end{array}$ & \\
\hline & Coefficients & & Coefficients & & Coefficients & \\
\hline Constant & -6.48 & $* * *$ & -29.43 & $* * *$ & -2.918462 & $* * *$ \\
\hline $\begin{array}{l}\text { Total number of } \\
\text { passengers }\end{array}$ & 1.56 & $* * *$ & $\begin{array}{c}-5.32 \\
\text { (instrument) }\end{array}$ & & & \\
\hline $\begin{array}{l}\text { Ratio commercial to } \\
\text { total revenue }\end{array}$ & 0.92 & $* * *$ & -2.63 & $* *$ & & \\
\hline GDP/capita & 0.62 & $* * *$ & 4.02 & $* * *$ & & \\
\hline$\%$ domestic passengers & & & & & 0.221227 & $* * *$ \\
\hline$\%$ business travelers & & & & & -0.452201 & $* *$ \\
\hline Traffic movements & & & & & 1.718344 & $* * *$ \\
\hline Adj. R-squared & 0.90 & & - & & 0.75 & \\
\hline F Test & 121.83 & & Chi2: 9.24 & & 33.45 & \\
\hline F Prob & 0.00 & & 0.00 & & 0.00 & \\
\hline No of obs & 41 & & 41 & & 31 & \\
\hline MAPE & $1.51 \%$ & & $5.39 \%$ & & $8.96 \%$ & \\
\hline
\end{tabular}

In a next step, we analyze the factors affecting commercial revenue per passenger. Table 5 reports the three models employed in this analysis. As Model 1 demonstrates, total commercial revenue is highly predictive of commercial revenue per passenger, which indicates that larger airports with a higher volume of commercial revenue typically also have higher commercial revenue on a per passenger basis. A possible explanation for this effect may be a larger number of retail facilities at large airport and that high-quality, high-spending retail outlets such as designer boutiques are typically only found in larger airports. The ratio of commercial to total revenue is again found to be significant thus confirming that a heavier emphasis on commercial over aviation-related sources of revenue is related to higher spending per passenger. In contrast to our prior expectations, the GDP/capita variable does not show the required significance level. To avoid a potential endogeneity bias, Model 2 instruments total commercial revenue and the ratio of commercial to total revenues. In this 2SLS framework, economic wealth (i.e. GDP/capita) shows the expected significance level indicating that passengers traveling in richer countries tend to spend more. Apart from that, airports in more developed countries can also expect to have higher revenue from non-retail commercial activities. Turning to the reduced-sample results estimated by Model 3, the 
proportion of domestic travelers and the volume of traffic movements exhibit a significantly positive influence on commercial revenue per passenger while the proportion of business travelers does not show any significance.

Table 5: Regression model for Total Commercial Revenue per Passenger ${ }^{4}$

\begin{tabular}{|c|c|c|c|c|c|c|}
\hline & $\begin{array}{c}\text { Model } 1 \\
(\text { OLS,log-log) } \\
\end{array}$ & & $\begin{array}{c}\text { Model 2 } \\
\text { (2SLS,log-log) } \\
\end{array}$ & & $\begin{array}{c}\text { Model 3 } \\
\text { (OLS,log-log) } \\
\end{array}$ & \\
\hline & Coefficients & & Coefficients & & Coefficients & \\
\hline Constant & -6.50 & $* * *$ & -9.61 & & -5.032057 & \\
\hline $\begin{array}{l}\text { Total number of } \\
\text { passengers }\end{array}$ & 0.16 & $*$ & $\begin{array}{c}-0.32 \\
\text { (instrument) }\end{array}$ & $* *$ & & \\
\hline $\begin{array}{l}\text { Ratio commercial to } \\
\text { total revenue }\end{array}$ & 0.92 & $* * *$ & 0.44 & $*$ & & \\
\hline GDP/capita & 0.63 & $* * *$ & 1.08 & $* * *$ & & \\
\hline$\%$ domestic passengers & & & & & 0.212917 & $* * *$ \\
\hline$\%$ business travelers & & & & & -0.225850 & \\
\hline Traffic movements & & & & & 0.535471 & $* * *$ \\
\hline Adj. R-squared & 0.86 & & 0.68 & & 0.40 & \\
\hline F Test & 85.82 & & Chi 2: 42.12 & & 6.22 & \\
\hline F Prob & 0.00 & & & & 0.00 & \\
\hline No of obs & 41 & & 41 & & 29 & \\
\hline MAPE & $11.1 \%$ & & $15.21 \%$ & & $13.22 \%$ & \\
\hline
\end{tabular}

Overall, commercial revenue (both absolute and on a per passenger basis) appears to be positively affected by the size of the airport, the level of domestic passengers, the level of leisure travelers and the income levels of the country the airport is located in. It should be noted that several search regressors contained in our database did not contribute significantly towards predicting commercial revenue and were therefore dropped from the models shown in the preceding tables to preserve degrees of freedom. These regressors include average delay times of flights, the physical structure of the terminal, the amount of retail space, the ratio of origin to transit passengers, the number of terminals, the structure of the terminals (linear, satellite and pier) as well type of airport operator (private, state or mixed).

\footnotetext{
${ }^{4}$ White heteroskedasticity-consistent standard errors \& covariance in all model estimations
} 
For airports trying to benchmark and implement commercial revenue strategies, it may be more relevant to measure revenue per sq.m. of retail space as the supply of retail space is largely within the control of airport operators whereas passenger volumes are not, at least not directly. A preliminary analysis of outliers and their impact on regression coefficients yielded that exclusion of outliers altered the parameter estimates of revenues per unit considerably, probably because of the particularly small sample size of this regression. Therefore, the standard OLS models were supplemented with robust regression to mitigate the distorting effect of outliers while at the same time avoiding arbitrary cutoff points for trimming the sample. Table 6 reports the results of this supplementary model both in OLS and Robust OLS specification. As before, the share of domestic passengers and the volume of traffic movements have a positive impact while the opposite is the case for business travelers. The most interesting variable in this model specification is possibly the supply of retail space. Prior expectations for this variable are not clear cut as both economies of scale and decreasing marginal revenue arguments appear to offset each other. However, the results of the regression estimations clearly show that higher supply of retail space per passenger depresses revenues on a per unit basis, pointing to decreasing marginal revenues as would be expected in a monopolistic structure such as retail space provision at airports.

Table 6: Regression model for commercial revenues per sq.m. retail space ${ }^{5}$

\begin{tabular}{|l|c|c|c|c|}
\hline & Model 1 (OLS) & & Model 2 (Robust OLS) $^{6}$ & \\
\hline & Coefficients & & Coefficients & \\
\hline Constant & -5.67 & $*$ & -0.35 & \\
\hline \% domestic passengers & 0.28 & $* * *$ & 0.46 & $* * *$ \\
\hline$\%$ business travelers & -0.27 & $*$ & -0.35 & $* *$ \\
\hline Traffic movements & 0.54 & $* * *$ & 0.52 & $* * *$ \\
\hline Retail space per PAX & -1.08 & $* * *$ & -0.90 & \\
\hline Adj. - squared & 0.68 & & -- & \\
\hline F Test & 13.91 & & 20.24 & \\
\hline F Prob & 0.00 & & 26 & \\
\hline No of obs & 26 & & \\
\hline
\end{tabular}

\footnotetext{
${ }^{5}$ White heteroskedasticity-consistent standard errors \& covariance in all model estimations

${ }^{6}$ Convergence achieved after 2 Huber iterations and 2 biweight iterations
} 


\section{Revenues from real estate operations}

Real estate operations are a subset of commercial revenues. Since retail and - to a lesser extent - office and convention space are crucial considerations in both airport planning and management, we model this revenue stream separately. Table 7 shows the model specifications and estimated parameters. The level of delayed flights is positive and marginally significant indicating a possible link between longer airport dwell times of passengers on delayed flights and retail, food and beverage sales which in turn tend to be reflected in a typical revenue-sharing lease arrangement with percentage rents. However, the share of flight delays fails the significance test in the robust regression. Economic development as measured by GDP per capita of the country in which an airport is located turned out to be a significant driver of real estate revenues, regardless of passenger origin and type (business/leisure). The share of passengers on intra-EU flights appears to be strongly linked to real estate revenue per capita. The results of the robust regression confirm largely the estimates obtained from OLS regression with the exception of delayed flights.

Table 7: Regression model for real estate revenues per passenger ${ }^{7}$

\begin{tabular}{|l|c|c|c|c|}
\hline & Model 1 (OLS) & & Model 2 (Robust OLS) $^{8}$ & \\
\hline & Coefficients & & Coefficients & \\
\hline Constant & -30.00 & & -30.49 & $* * *$ \\
\hline Delayed flights (\%) & 3.78 & $*$ & 3.96 & \\
\hline GDP/capita & 2.78 & $* * *$ & 2.83 & $* * *$ \\
\hline Passengers intraEU (\%) & -2.40 & $* * *$ & -2.56 & \\
\hline & & & & \\
\hline Adj. - squared & 0.56 & & 8.95 & \\
\hline F Test & 9.26 & & 0.00 & \\
\hline F Prob & 0.00 & & 30 & \\
\hline No of obs & 30 & & \\
\hline
\end{tabular}

\footnotetext{
${ }^{7}$ White heteroskedasticity-consistent standard errors \& covariance in all model estimations

${ }^{8}$ Convergence achieved after 5 Huber iterations and 16 biweight iterations
} 


\section{CONCLUSIONS}

This cross-sectional analysis of 45 European airports shows that the size of an airport is a major driver of commercial revenue for both absolute levels and on a per passenger basis as well as aviation-related revenues. National income per capita of the country in which the airport is located is also a positive and significant determinant. The results of this analysis are in line with the majority of previous studies which find that the share of business travelers exerts a negative influence on commercial revenues per passenger but disagrees with these studies in that it finds that the share of domestic passengers, not international passengers tends to increase commercial revenues. A possible reason for this disagreement is that this study focuses exclusively on European airports while most existing studies are either global or focus on North America. Spending patterns of passengers at European airports may differ significantly due to differences in regulations such as the abolition of duty free shops for intra-EU flights or increased security measures that may have a larger detrimental effect in regions of the world such as Europe where average flight times and distances tend to be short. Significant predictors of real estate revenue per passengers include GDP per capita, share of intra-EU flights and percentage of delayed flights (depending on model specification).

The practical implications of this study for the operational strategies of airports are not straightforward, however, as some of the most important drivers of commercial revenue identified here are beyond the control of airport management strategies. These factors include the general level of economic development and the factors relating to the size and volume of airports beyond the respective capacity constraints. Among the factors that airports may be able to influence, at least indirectly and in the medium to long run, is the composition of passenger structure and the supply of retail space. It appears, however, that very few airports have a tightly integrated development strategy that attempts to harness potential synergy effects between these two business areas.

Overall, this study broadly confirms the determinants of commercial revenues found for North American and global airports, albeit with some notable exceptions. Further research is needed to explore the causal and behavioral processes underlying these findings and larger samples of airports are required to remove the limitations associated with relatively small samples. A more thorough investigation of financial characteristics of commercial activities (rental cash flows, yields etc.) is also required to assess more comprehensively which commercial strategies airports can be considered successful. Finally, as the database underlying the present study will be expanded and updated in the future, the number of observations will increase and enable additional types of analysis such as time series and panel data frameworks. 


\section{REFERENCES}

Aldridge, K., Carreno, M., Ison, S., Rye, T., Straker, I., 2001. Car parking management at airports: A special case? Transport Policy, 2001, 13, 511-521.

Appold, S., Kasarda, J. D.,2009. Governing the aerotropolis. Global Airport Cities, 2009 (1), 12-17.

Appold, S. J., Kasarda, J. D.: The appropriate scale of US airport retail activities. Journal of Air Transport Management, 2006 (12), 277-287.

Benham, D., 2009. Successfully optimising retail space from existing airport facilities. Journal of Airport Management 4, 8-13.

Castillo-Manzano, J.I., 2010. Determinants of commercial revenues at airports: Lessons learned from Spanish regional airports. Tourism Management 31/6, 788-796.

Deloitte (eds.), 2009. Europäische Flughafenbetreiber - Hohe Profitabilitätsniveaus sind nur eine Seite der Medaille, Report 2009.

Freathy, P., 2004. The commercialisation of European airports: successful strategies in a decade of turbulence? Journal of Air Transport Management 2004 (10), 191-197.

Freathy, P., O'Connell, F., 1999. A typology of European airport retailing The Service Industries Journal 1999 (3), $119-134$.

Geuens, M., Vantomme, D., Brengman, M., 2004. Developing a typology of airport shoppers. Tourism Management $2004(25), 615-622$.

Gillen, D., Lall, A., 2004. Competitive advantage of low-cost carriers: some implications for airports. Journal of Air Transport Management 2004(10), 41-50.

Graham, A., 2008. Managing Airports - An international perspective, 3rd edition, Oxford/Burlington.

Hsu, C.-I., Chao, C.-C., 2005. Space allocation for commercial activities at international passenger terminals. Transportation Research 2005 (1), 29-51.

Kim, H.-B., Shin, J.-H., 2001. A Contextual Investigation of the Operation and Management of Airport Concessions. Tourism Management 2001 (22), 149-155.

Martel, F., 2009. External factors and their impact on non-aviation revenue. Journal of Airport Management 2009 (4), 337-344.

Morrison, W. G., 2009. Real estate, factory outlets and bricks: A note on non-aviation activities at commercial airports. Journal of Air Transport Management 3, 112-115.

Papatheodorou, A., Lei, Z., 2006. Leisure travel in Europe and airline business models: A study of regional airports in Great Britain. Journal of Air Transport Management 12/1, 47-52.

Poungias, P., 2009. Airport city developments: An airport investor's perspective. Journal of Airport Management 2009 (4), 14- 22.

The Moodie Report (eds.), 2007. The Airport Retail Study - Fourth Edition 2006/07. Brentford. 
The Moodie Report (eds.), 2009. The Airport Commercial Revenues Study - Fifth Edition 2008/09. Brentford..

Torres, E., Domínguez, J. S., Valdes, L., Aza, R., 2005. Passenger waiting time in an airport and expenditure carried out in the commercial area. Journal of Air Transport Management 2005 (6), 363-367.

Volkova, N., 2009. Determinants of retail revenue for today's airports. GAP Project Working Paper, Berlin.

Zenglein, M. J., Müller, J., 2007. Non-Aviation Revenue in the Airport Business - Evaluating Performance Measurement for a Changing Value Proposition, GAP Project Working Paper, Berlin.

Zhang, A., \& Zhang, Y. 1997. Concession revenue and optimal airport pricing. Transportation Research Part E: Logistics and Transportation Review, 33, 287-296. 
Appendix: Table A1: Variable definitions

\begin{tabular}{|c|c|}
\hline Variable & Definition \\
\hline Total revenue & Combined airport income from all operations (aviation, non-aviation and other) \\
\hline Aviation / Aeronautical revenue & $\begin{array}{l}\text { airport operator's income from pure aeronautical related operations such as ground handling, passenger and } \\
\text { cargo transfer. }\end{array}$ \\
\hline Non-Aviation / Non-Aeronautical revenues & $\begin{array}{l}\text { income from activities that are not directly relate to aeronautical operations such as retailing, car parking, real } \\
\text { estate etc. }\end{array}$ \\
\hline Other revenues & $\begin{array}{l}\text { income from other activities that are not assigned to either aeronautical or non-aeronautical activities such as } \\
\text { investment in financial products, consulting activities. }\end{array}$ \\
\hline Commercial revenues & $\begin{array}{l}\text { income from retail and commercial activities (duty free, news \& gifts, specialty retailing, food \& beverage and } \\
\text { currency exchange) }\end{array}$ \\
\hline Real estate revenues & $\begin{array}{l}\text { airport operator's income from real estate operations including developing, managing and renting out space to } \\
\text { tenants, such as retail space lettings to airport concessionaires }\end{array}$ \\
\hline GDP per capita & $\begin{array}{l}\text { Gross Domestic Product per capita of the country where the respected airport is located in purchasing power } \\
\text { parities in } 2008\end{array}$ \\
\hline Traffic movements & total annual sum of incoming and outgoing airplanes during at an airport (equal to TTF - total flights) \\
\hline Retail space & $\begin{array}{l}\text { space inside or outside the terminals provided for commercial activities by the airports, excluding any parking } \\
\text { spaces and facilities as well as office buildings }\end{array}$ \\
\hline Business travelers & total number of passengers using an airport for predominantly business-related travel \\
\hline Leisure travelers & total number of passengers using an airport for predominantly leisure-related travel \\
\hline Domestic travelers & total number of passengers traveling to a domestic destination (regardless of their nationality) \\
\hline International travelers & total number of passengers traveling to an international destination (regardless of their nationality) \\
\hline Origin of destination & $\begin{array}{l}\text { total number of passengers using an airport as the starting point for a journey that will be routed directly to the } \\
\text { final destination (no en route stops or connecting flights) }\end{array}$ \\
\hline Numbers of destination & the total number of destinations (airports) that are served by an airport via direct connections \\
\hline Punctuality of arrivals & the total number of airplanes arriving on schedule in 2008 , i.e. within 15 minutes of the scheduled time \\
\hline Punctuality of departures & the total number of airplanes departing on schedule in 2008 , i.e. within 15 minutes of the scheduled time \\
\hline Total passengers & total number of passengers departing or arriving at an airport in 2008 \\
\hline Ratio commercial to total revenue & Percentage of revenue gained from commercial activities relative to the airport's total revenue \\
\hline Delayed flights & Ratio of flights departing later than scheduled as a percentage of total flight departures of an airport in 2008 \\
\hline
\end{tabular}

